\title{
PENGARUH KOMPOSISI DAN FREKUENSI APLIKASI UREA DENGAN ARANG SEKAM PADI PADA PERTUMBUHAN BIBIT KAKAO (Theobroma cacao L.)
}

\author{
The Effect Of Composition And Frecuency Of Urea Applicatoins With Rice Husk Charcoal \\ On Cacao Seed Growth (Theobroma cacao L.)
}

DWI YULIANAYAN SARI ${ }^{1 *}$, YONATHAN PARAPASAN², RIJADI SUBIANTORO²

${ }^{1}$ Program Studi Produksi dan Manajemen Industri Perkebunan Politeknik Negeri Lampung

2Jurusan Budidaya Tanaman Perkebunan Politeknik Negeri Lampung

JI. Soekarno-Hatta No. 10 Rajaasa Bandar lampung 35144 Telf (0721) 703995 Fax (0721) 787309

*Email: dwiyulianayan2010@gmail.com

\begin{abstract}
Fertilizer can be used as a tool enchane plant growth and soil fertility, because by applying fertilizer it can supply nutrient in the soil so that plant growth is optimal. The type of fertilizer used is organic fertilizer (rice hust charcoal) and anrganic (urea) which acts as an increase in plant growth and devolopment and increase soil fertility. This study aims to obtain the effect of the composition of the application frequency of the mixture of urea and hust charcoal on the growth of cacao seeds, get the best effect of the composition of the urea fertilizer and husk charcoal on the growth of cacao seedling and get an interaction between the composition of the application frequency of urea and husk charcoal on the growth cacao seed. This research was carried out in the practice garden of the devolopment of plantation plant cultivation and Lampung State analysis laboratory. The study was conducted from January to May 2019. The study was arranged in a factorial block design (RBD) with 2 factor, the first factor composition fertilizer and second factor application frequency of urea and rice husk charcoal. The research showed there was on effect of the best composition of the mixture of urea dan husk charcoal on the growth of cacao seedling in the (1:2) with application frequency 2 time, and there was an interaction between the composition of the application frequency of urea and husk charcoal on the growth of cacao seedling in all observed variables except for abserving stem diameter, $N$ plant tissue and plant sttover dry weight.
\end{abstract}

Keyword: Application frecuency, composition, urea, rice husk charcoal

\section{PENDAHULUAN}

Kakao (Theobroma cacao L.) merupakan tanaman perkebunan yang bernilai ekonomi tinggi dan menempati urutan ketiga setelah kelapa sawit dan karet pada sub sektor perkebunan (Panjaitan dan Idwar, 2015). Tingkat produksi tanaman kakao ditentukan oleh perlakuan yang diberikan selama dipembibitan awal. Penyemaian bibit dimaksudkan untuk mendapatkan kecambah kecambah yang baik dan seragam pertumbuhannya. Biji yang dipilih dapat diperoleh dari pohon yang mempunyai produksi tinggi serta bebas dari hama dan penyakit. Bibit dapat tumbuh dengan optimal perlu diciptakan media tanam yang mendukung dan pemberian pupuk sebagai penyedia unsur hara, komposisi pupuk organik dan anorganik dapat mempengaruhi pertumbuhan tanaman seperti tinggi tanaman, diameter batang dan luas daun (Onggo dkk., 2017) Arang sekam padi merupakan salah satu pupuk organik yang dapat dipercaya dapat meningkatkan ketersediann unsur hara dalam tanah, berfungsi sebagai ziolit, dan menyimpan unsur hara dalam tanah sehingga tidak mudah tercuci oleh air dan sangat mudah dilepaskan ketika dibutuhkan atau diambil oleh tanaman (Supriyanto dan Fiona, 2010). Urea merupakan pupuk anorganik yang mempunyai kandungan nitrogen $46 \%$ dan merupakan golongan pupuk yang hidrokopis dimana pada kelembaban $73 \%$ pupuk ini mulai menarik dari udara sehingga mudah hilang dari tanah. Untuk mengurangi keluarnya kandungan nitrogen dari dalam tanah perlu teknologi baru termasuk aplikasi $\mathrm{N}$ bersama dengan arang sekam padi (Nurahmi dkk., 2013).

\section{METODE PENELITIAN}

Penelitian ini telah dilaksanakan di kebun praktik, Jurusan Budidaya Tanaman Perkebunan, Politeknik Negeri Lampung. Selama 5 bulan, dari bulan Januari sampai Mei 2019. Bahan yang digunakan adalah tanah topsoil, bibit kakao lokal, pupuk urea, pupuk SP.36, pupuk $\mathrm{KCl}$, Arang sekam, fungisida, air dan pasir. Alat yang digunakan 
adalah cangkul, ember, mistar, jangka sorong, paranet, gembor, timbangan, penggaris, bambu, tali plastik, polibag $20 \mathrm{~cm} \times 30 \mathrm{~cm}$, ayakan, shading net, oven, gembor, ajir.Penelitian dilaksanakan dengan menggunakan Rancangan Acak Kelompok (RAK) pola faktorial, yang terdiri atas dua faktor perlakuan dan setiap komposisi perlakuan diulang 3 kali.

Faktor pertama adalah Frekuensi aplikasi yang terdiri atas 2 taraf:

F1 : 1 kali aplikasi

F2 : 2 kali aplikasi

Frekuensi aplikasi pupuk satu kali dilakukan pada umur 1,5 bulan, dan frekuensi aplikasi pupuk dua kali dilakukan pada umur 1,5 bulan dan 2,5 bulan.

Faktor kedua adalah komposisi Urea dan arang sekam yang terdiri dari 4 taraf.

K0 :1:0 (Urea 4 gr.polibeg ${ }^{-1}+$ arang sekam 0 gr.polibeg-1)

K1 :2:1 (Urea 4 gr.polibeg ${ }^{-1}+$ arang sekam 2 gr.polibeg-1)

K2 :1:1 (Urea 4 gr.polibeg-1 ${ }^{-1}$ arang sekam 4 gr.polibeg-1)

K3 :1:2 (Urea 4 gr.polibeg- ${ }^{-1}+$ arang sekam 8 gr.polibeg-1)
Pengamatan dilakukan setiap dua minggu sekali dan akhir minggu penanaman (umur tanaman 5 bulan). Variabel yang diamati yaitu tinggi tanaman, diameter batang, jumlah daun, luas daun, bobot kering brangkasan, serta kandungan $\mathrm{N}$ jaringan.

\section{HASIL DAN PEMBAHASAN}

\section{Tinggi tanaman}

Hasil analisis sidik ragam pada $\begin{array}{llllll}\text { pengamatan } & 7 & \text { MST } & \text { sampai } 19 & \text { MST }\end{array}$ menunjukkan bahwa frekuensi aplikasi dan komposisi urea dan arang sekam pada semua pengamatan berpengaruh sangat nyata terhadap tinggi tanaman, demikian juga interaksi antara frekuensi aplikasi dengan komposisi urea dangan arang sekam padi berpengaruh nyata terhadap tinggi tanaman pada pengamatan 7 MST, 16 MST 19 MST berpengaruh nyata tetapi pada pengamatan 10 MST dan 13 MST berpengaruh sangat nyata pada tinggi tanaman. Pengaruh interaksi antara frekuensi aplikasi dan komposisi urea dangan arang sekam padi pada tinggi tanaman 19 MST disajikan pada Tabel 1.

Tabel 1. Pengaruh interaksi frekuensi aplikasi dan komposisi urea dengan arang sekam padi terhadap tinggi tanaman pada 7 MST - 19 MST

\begin{tabular}{|c|c|c|c|c|c|c|}
\hline $\begin{array}{l}\text { Komposisi urea dan } \\
\text { arang sekam }\end{array}$ & $\begin{array}{l}\text { Frekuensi } \\
\text { Aplikasi }\end{array}$ & $7 \mathrm{MST}$ & $10 \mathrm{MST}$ & $13 \mathrm{MST}$ & $16 \mathrm{MST}$ & $19 \mathrm{MST}$ \\
\hline K0 (1:0) urea + arang sekam & $\mathrm{F} 1$ & $24,90^{d}$ & $30,35^{d}$ & $30,35^{d}$ & $33,40^{d}$ & $36,98^{d}$ \\
\hline K1 (2:1) urea + arang sekam & & $28,13^{c}$ & $34,18^{c}$ & $34,35^{c}$ & $36,68^{c}$ & $39,45^{c}$ \\
\hline K2 (1:1) urea + arang sekam & & $32,05^{b}$ & $37,70^{\mathrm{b}}$ & $37,70^{\mathrm{b}}$ & $40,88^{b}$ & $43,68^{b}$ \\
\hline $\mathrm{K} 3(1: 2)$ urea + arang sekam & & $35,58^{b}$ & $42,33^{b}$ & $42,33^{b}$ & $44,15^{b}$ & $47,15^{\mathrm{b}}$ \\
\hline $\mathrm{K} 0(1: 0)$ urea + arang sekam & $\mathrm{F} 2$ & $27,28^{c}$ & $34,78^{c}$ & $34,78^{c}$ & $37,10^{c}$ & $41,35^{c}$ \\
\hline K1 (1:2) urea + arang sekam & & $29,19^{c}$ & $34,38^{c}$ & $34,38^{c}$ & $37,13^{c}$ & $40,90^{c}$ \\
\hline K2 (1:1) urea + arang sekam & & $33,05^{\mathrm{b}}$ & $38,55^{b}$ & $38,55^{b}$ & $41,08^{b}$ & $44,03^{b}$ \\
\hline K3 (1:2) urea + arang sekam & & $39,43^{a}$ & $45,68^{a}$ & $45,68^{a}$ & $48,25^{a}$ & $52,15^{a}$ \\
\hline BNT & & 1,88 & 2,16 & 2,42 & 3,14 & 3,53 \\
\hline
\end{tabular}

Keterangan: Angka-angka yang diikuti huruf yang sama menunjukkan tidak berbeda nyata pada uji BNT taraf $5 \%$.

Tabel 1 menunjukkan bahwa kombinasi perlakuan F2K3 menunjukkan tinggi tanaman tertinggi, sedangkan pada perlakuan F1K0 menunjukkan tinggi tanaman terendah seperti yang ditunjukkan dalam Gambar 1. Perlakuan F2K2 tidak berbeda nyata dengan F1K3 tetapi berbeda nyata dengan perlakuan F2K0, F1K1, F2K1 dan F1K0. Hal ini diduga terjadi karena frekuensi aplikasi dan komposisi urea dangan arang sekam padi (biochar) yang berbeda dapat menyediakan unsur hara yang berbeda juga bagi tanaman sehingga pertumbuhan tanaman berbeda. Berdasarkan hasil analisis penunjang, kandungan $\mathrm{N}$ pada tanah yang digunakan cenderung tinggi tetapi kebutuhan $\mathrm{N}$ dalam tanaman belum tercukupi sehingga penambahan pupuk urea sangat berpengaruh terhadap pertumbuhan vegetatif tanaman. Saragih dkk. (2013) menyatakan bahwa dengan adanya interval waktu aplikasi urea maka unsur hara yang diaplikasikan dapat selalu tersedia bagi tanaman, sehingga kebutuhan unsur hara $\mathrm{N}$ bagi tanaman dapat terpenuhi. Menurut tersedianya unsur hara yang cukup dan berimbang dapat menyebabkan proses pembelahan, pembesaran dan pemanjangan sel berlangsung dengan cepat sehingga organ pada tanaman dapat tumbuh dengan cepat.

\section{Diameter batang}

Hasil analisis sidik ragam diameter batang menunjukkan bahwa frekuensi aplikasi pengamatan 7 MST sampai dengan 19 MST menunjukkan pengaruh sangat nyata, demikian juga komposisi urea dangan arang 
sekam padi pada diameter batang menunjukkan pengaruh sangat nyata. Akan tetapi interaksi antara frekuensi aplikasi dan komposisi urea dengan arang sekam padi menunjukkan berbeda sangat nyata pada pengamatan $7 \mathrm{MST}$, tetapi pada $10 \mathrm{MST} 13$ MST, 15 MST dan 19 MST tidak berbeda nyata.

Tabel 2. Pengaruh mandiri frekuensi dan komposisi urea dengan arang sekam padi terhadap diameter tanaman

\begin{tabular}{lccccc}
\hline \multirow{2}{*}{ Perlakuan } & \multicolumn{5}{c}{ Waktu pengamatan (MST) } \\
\cline { 2 - 6 } & $7 \mathrm{MST}$ & $10 \mathrm{MST}$ & $13 \mathrm{MST}$ & $16 \mathrm{MST}$ & $19 \mathrm{MST}$ \\
\hline Pengaruh mandiri Frekuensi Aplikasi & & & & & \\
Frekuensi 1 kali & $0,69^{\mathrm{b}}$ & $0,73^{\mathrm{b}}$ & $0,77^{\mathrm{b}}$ & $0,82^{\mathrm{b}}$ & $0,88^{\mathrm{b}}$ \\
Frekuensi 2 kali & $1,41^{\mathrm{a}}$ & $1,53^{\mathrm{a}}$ & $1,62^{\mathrm{a}}$ & $1,71^{\mathrm{a}}$ & $1,82^{\mathrm{a}}$ \\
\hline BNT & 0,01 & 0,01 & 0,02 & 0,02 & 0,02 \\
\hline Pengaruh mandiri & & & & \\
Komposisi urea dangan arang sekam padi & $0,61^{\mathrm{c}}$ & $0,66^{\mathrm{d}}$ & $0,72^{\mathrm{c}}$ & $0,78^{\mathrm{c}}$ & $0,82^{\mathrm{d}}$ \\
K0 (1:0)urea+arang sekam & $0,71^{\mathrm{b}}$ & $0,74^{\mathrm{c}}$ & $0,78^{\mathrm{b}}$ & $0,83^{\mathrm{b}}$ & $0,89^{\mathrm{c}}$ \\
K1 (2:1)urea+arang sekam & $0,70^{\mathrm{b}}$ & $0,77^{\mathrm{b}}$ & $0,80^{\mathrm{b}}$ & $0,86^{\mathrm{a}}$ & $0,92^{\mathrm{b}}$ \\
K2 (1:1)urea+arang sekam & $0,78^{\mathrm{a}}$ & $0,82^{\mathrm{a}}$ & $0,85^{\mathrm{a}}$ & $0,89^{\mathrm{a}}$ & $0,95^{\mathrm{a}}$ \\
K3 (1:2)urea+arang sekam & 0,02 & 0,02 & 0,02 & 0,03 & 0,03 \\
\hline BNT & \multicolumn{5}{c}{0.03} \\
\hline Keterangan: & Angka-angka yang diikuti huruf yang sama pada tiap kolom menunjukkan tidak berbeda nyata pada uji
\end{tabular}

Tabel 2 menunjukkan bahwa pengaruh mandiri perlakuan frekuensi aplikasi terhadap diameter batang berbeda nyata, perlakuan 2 kali memberikan hasil diameter batang cenderung lebih besar $(1,82 \mathrm{~cm})$ dibandingkan dengan perlakuan frekuensi 1 kali, hal ini diduga frekuensi aplikasi 2 kali sebagian besar unsur $\mathrm{N}$ dari urea tersimpan dalam tanah dan terserap oleh akar tanaman sehingga dapat menambah diameter batang tanaman kakao. Hal ini diduga karena unsur $\mathrm{N}$ lebih banyak tersedia jika diberikan secara bertahap karena sifat $\mathrm{N}$ yang bersifat mobil.

Pengaruh mandiri perlakuan komposisi urea dan arang sekam menunjukkan bahwa perlakuan K3 (1:2) menunjukkan diameter batang tertinggi, kemudian disusul perlakuan $\mathrm{K} 2$, K1 dan terkecil adalah $\mathrm{K} 0$. Hal ini diduga terjadi karena pada perlakuan K3 komposisi urea dangan arang sekam padi lebih tinggi sehingga unsur hara $\mathrm{N}$ yang diikat sementara oleh arang sekam lebih banyak pada perlakuan $\mathrm{K} 3$ dengan semakin menurun pada $\mathrm{K} 2$ dan $\mathrm{K} 1$ kemudian terendah adalah $\mathrm{K} 0$.

Berdasarkan hasil analisis penunjang bahwa kandungan $\mathrm{P}$ dalam tanah sangat rendah tetapi setelah diberikan perlakuan kandungan $P$ tanah meningkat sehingga merangsang pembelahan sel tanaman dan memperbesar jaringan sel. Fatimah \& Handarto (2008) menyatakan kadar N (nitrogen) pada media tanam yang tinggi sangat mempengaruhi pertumbuhan vegetatif, dengan penambahan volume sel tanaman seperti (tinggi dan diameter batang).

\section{Jumlah daun (helai)}

Hasil analisis sidik ragam jumlah daun pada pengamatan $7 \mathrm{MST}, 10 \mathrm{MST}, 13 \mathrm{MST}$, 16 MST dan 19 MST (Tabel 3), menunjukkan bahwa frekuensi aplikasi berpengaruh sangat nyata pada pengamatan 16 MST dan 19 MST, dan berpengaruh nyata pada $13 \mathrm{MST}$, tetapi pada pengamatan 7 MST dan 10 MST tidak memberikan pengaruh nyata. Komposisi urea dengan arang sekam memberikan pengaruh sangat nyata pada semua pengamatan, dan interaksi frekuensi Aplikasi dan komposisi urea dangan arang sekam padi menunjukkan tidak berbeda nyata pada semua pengamatan kecuali pada pengamatan 19 MST. Hasil analisis sidik ragam pada 19 MST menunjukkan bahwa frekuensi aplikasi dan komposisi urea dengan arang sekam berpengaruh sangat nyata terhadap jumlah daun kemudian interaksi urea dan arang sekam berpengaruh nyata terhadap jumlah daun. 
Tabel 3. Pengaruh mandiri komposisi dan frekuensi urea dengan arang sekam padi terhadap jumlah daun pada 7 MST sampai 19 MST

\begin{tabular}{|c|c|c|c|c|c|}
\hline \multirow{2}{*}{ Perlakuan } & \multicolumn{4}{|c|}{ Waktu pengamatan (MST) } & \multirow[b]{2}{*}{$19 \mathrm{MST}$} \\
\hline & $7 \mathrm{MST}$ & $10 \mathrm{MST}$ & $13 \mathrm{MST}$ & $16 \mathrm{MST}$ & \\
\hline \multicolumn{6}{|l|}{ Frekuensi Aplikasi } \\
\hline Frekuensi 1 kali & $6,50^{b}$ & $9,31^{b}$ & $12,25^{b}$ & $15,38^{b}$ & $19,06^{a}$ \\
\hline Frekuensi 2 kali & $13,63^{a}$ & $19,5^{a}$ & $27,88^{a}$ & $36,38^{a}$ & $45,00^{a}$ \\
\hline BNT & 0,93 & 0,96 & 1,71 & 0,63 & 0,90 \\
\hline \multicolumn{6}{|c|}{ Komposisi urea dangan arang sekam padi } \\
\hline K0 (1:0)urea+arang sekam & $5,25^{b}$ & $7,75^{\mathrm{b}}$ & $10,13^{b}$ & $13,75^{\mathrm{d}}$ & $17,88^{b}$ \\
\hline K1 (2:1)urea+arang sekam & $6,50^{b}$ & $9,88^{a}$ & $12,88^{a}$ & $16,00^{c}$ & $19,50^{b}$ \\
\hline K2 (1:1)urea+arang sekam & $7,38^{b}$ & $10,13^{a}$ & $14,50^{\mathrm{a}}$ & 18,13 & $22,38^{b}$ \\
\hline K3 (1:2)urea+arang sekam & $7,50^{\mathrm{b}}$ & $10,38^{a}$ & $14,88^{a}$ & $19,25^{a}$ & $23,38^{a}$ \\
\hline BNT & 1,31 & 1,36 & 2,43 & 0,89 & 1,28 \\
\hline
\end{tabular}

Tabel 3 menunjukkan bahwa kombinasi perlakuan F2K3 menunjukkan jumlah daun tertinggi pada pengamatan 19 MST $(23,38)$, sedangkan pada perlakuan F1K0 menunjukkan jumlah daun terendah $(17,88)$. Perlakuan F2K3, F1K3 dan F2K2 tidak berbeda nyata, tetapi berbeda pada perlakuan F1K2, F2K1, F2K0, F1K1 dan F1K0, Hal ini terjadi karena jumlah daun tanaman kakao dipengaruhi oleh adanya unsur N. Pada analisis penunjang unsur hara $\mathrm{N}$ tanah cenderung tinggi sehingga frekuensi aplikasi dan komposisi urea dan arang sekam berpengaruh nyata pada jumlah daun. Agustin dan Riniarti (2014), menyatakan bahwa perkembangan sistem perakaran akan mempengaruhi perkembangan tajuk bibit yaitu pertumbuhan tinggi bibit dan jumlah daun.

\section{Luas daun}

Hasil analisis sidik ragam pada 19 MST) menunjukkan bahwa komposisi serta frekuensi aplikasi urea dengan arang sekam menunjukkan beda nyata. Interaksi antara frekuensi aplikasi dan komposisi urea dengan arang sekam berpengaruh nyata terhadap luas daun. Pengaruh frekuensi aplikasi dan komposisi urea dengan arang sekam padi pada luas daun kakao disajikan pada Tabel 4 .

Tabel 4. Pengaruh interaksi komposisi dan frekuensi aplikasi urea dengan arang sekam padi terhadap luas daun tanaman pada 19 MST

\begin{tabular}{ccccc}
\hline \multirow{2}{*}{$\begin{array}{c}\text { Frekuensi } \\
\text { aplikasi }\end{array}$} & \multicolumn{4}{c}{ Komposisi urea dangan arang sekam padi } \\
\cline { 2 - 5 } F1 & $71,80^{\mathrm{c}}$ & $111,23^{\mathrm{b}}$ & $113,97^{\mathrm{b}}$ & $121,16^{\mathrm{b}}$ \\
F2 & $80,23^{\mathrm{c}}$ & $116,22^{\mathrm{b}}$ & $120,41^{\mathrm{b}}$ & $152,36^{\mathrm{a}}$ \\
\hline BNT & \multicolumn{3}{c}{9,41} \\
\hline Keterangai)
\end{tabular}

Tabel 4 menunjukkan bahwa luas daun dengan kombinasi tertinggi pada perlakuan F2K3 $(152,36)$ dan kombinasi terendah pada perlakuan F1K0 (71,80). Hal ini diduga karena adanya faktor lingkungan seperti intensitas cahaya yang merupakan salah satu penyebab bertambahnya luas. Semakin besar nilai luas daun maka semakin meningkat kapasitas daun untuk melakukan fotosintesis. selanjutnya fotosintat ditranslokasikan ke seluruh organ tanaman untuk dimanfaatkan dalam proses pertumbuhan dan perkembangan sesuai fase pertumbuhannya
(Qodiriyah, 2019). Tanaman yang cukup mendapat suplai nitrogen akan membentuk daun yang memiliki helai daun lebih luas dengan kandungan klorofil yang lebih tinggi, sehingga tanaman mampu menghasilkan karbohidrat/asimilat dalam jumlah yang tinggi untuk menopang pertumbuhan vegetatif (Gustia, 2013).

\section{Bobot Kering Brangkasan}

Hasil analisis sidik ragam pada pengamatan 19 MST menunjukkan bahwa frekuensi aplikasi memberikan pengaruh 
sangat nyata dan komposisi urea dengan arang sekam padi memberikan pengaruh sangat nyata terhadap bobot kering brangkasan, sedangkan interaksi antara frekuensi aplikasi dan komposisi urea dengan arang sekam berbeda tidak nyata terhadap bobot kering brangkasan tanaman. Pengaruh mandiri disajikan pada Tabel 5 .

Tabel 5 menunjukkan bahwa pengaruh mandiri frekuensi aplikasi urea dengan arang sekam terhadap bobot kering tanaman tertinggi pada frekuensi 2 kali $(61,33)$ dan terendah pada frekuensi 1 kali $(28,43)$. Hal diduga ini karena sedikitnya air yang terkandung pada bibit kakao yang digunakan sehingga bobot kering brangkasan menjadi rendah, jika kebutuhan air pada tanaman tidak tercukupi hingga berakhirnya fase vegetatif maka proses fotosintesis tidak lancar dan mengakibatkan bobot kering tanaman menjadi rendah (Audi, 2016). Komposisi urea dangan arang sekam padi pada bobot kering tanaman perlakuan K3 cenderung lebih tingg $(33,35 \mathrm{~g})$ kemudian disusul, perlakuan $\mathrm{K}_{1}$ dan $\mathrm{K} 2$ dan terkecil K0. Hal ini diduga karena serapan nitrogen pengaruhi kadar nitrogen dan produksi bahan kering, sehingga semakin Tinggi serapan nitrogen semakin tinggi produksi bahan keringnya (Fajarditta, 2012). Status nutrisi suatu tanaman merupakan indikator yang menentukan baik tidaknya suatu pertumbuhan dan mencerminkan akumulasi senyawa organik yang berhasil disintesis oleh tanaman perkembangan tanaman sehingga erat kaitannya dengan ketersediaan hara (Uli dkk., 2014).

Tabel 5. Pengaruh mandiri frekuensi dan komposisi urea dengan arang sekam padi terhadap variabel berat kering brangkasan

\begin{tabular}{lc}
\hline \multicolumn{1}{c}{ Perlakuan } & Bobot Kering Brangkasan $(\mathrm{g})$ \\
\hline Frekuensi aplikasi & $28,43^{\mathrm{b}}$ \\
F1 (Frekuensi 1 kali) & $61,33^{\mathrm{a}}$ \\
F2 (Frekuensi 2 kali) & 0,961 \\
\hline BNT & \\
\hline Komposisi urea dan arang sekam padi & $20,05^{\mathrm{d}}$ \\
K0 (1:0) Urea + arang sekam padi & $26,61^{\mathrm{c}}$ \\
K1 (2:1) Urea + arang sekam padi & $28,01^{\mathrm{b}}$ \\
K2 (1:1) Urea + arang sekam padi & $33,35^{\mathrm{a}}$ \\
K3 (1:2) Urea + arang sekam padi & 1,360 \\
\hline BNT &
\end{tabular}

Tabel 6. Pengaruh mandiri frekuensi dan komposisi urea dengan arang sekam padi terhadap $\mathrm{N}$ jaringan tanaman

\begin{tabular}{lc}
\hline \multicolumn{1}{c}{ Perlakuan } & N Jaringan \\
\hline Pengaruh mandiri frekuensi aplikasi & \\
F1 (Frekuensi 1 kali & $56,45^{\mathrm{b}}$ \\
F2(Frekuensi 2 kali) & $125,89^{\mathrm{a}}$ \\
\hline BNT & 1,96 \\
\hline Komposisi urea dan arang sekam padi & \\
K0 (1:0) Urea + arang sekam padi & $46,60^{\mathrm{d}}$ \\
K1 (2:1) Urea + arang sekam padi & $53,86^{\mathrm{c}}$ \\
K2 (1:1) Urea + arang sekam padi & $63,57^{\mathrm{b}}$ \\
K3 (1:2) Urea + arang sekam padi & $74,76^{\mathrm{a}}$ \\
\hline BNT & 2,77 \\
\hline Keterangan: Angka-angka yang diikuti huruf yang sama menunjukkan tidak berbeda nyata pada uji BNT taraf &
\end{tabular}

\section{Nitrogen Jaringan Tanaman}

Hasil analisis sidik ragam nitrogen $(\mathrm{N})$ jaringan tanaman pada 19 MST menunjukkan bahwa frekuensi aplikasi dan komposisi memberikan pengaruh sangat nyata sedangkan interaksi urea dan arang sekam tidak berbeda nyata terhadap $\mathrm{N}$ jaringan tanaman. Pengaruh mandiri frekuensi aplikasi urea dengan arang sekam padi menunjukkan bahwa kandungan $\mathrm{N}$ jaringan tanaman tertinggi pada perlakuan frekuensi 2 kali $(125,89)$ dan kandungan $\mathrm{N}$ jaringan tanaman terendah frekuensi 1 kali $(56,45)$. Hal ini diduga karena pemberian $\mathrm{N}$ yang tinggi maka jumlah serapan nitrogen meningkat dengan bertambahnya jumlah pupuk yang diberikan. 
Dwidjoseputro (1980) menyatakan bahwa serapan hara oleh tanaman sangat dipengaruhi oleh kadar dan ketersediaan hara dalam tanah.

Pengaruh mandiri perlakuan K3 memberikan hasil tertinggi $(74,76)$ kemudian disusul perlakuan $\mathrm{K} 2, \mathrm{~K} 1$ dan terendah $\mathrm{K} 0$. Hal ini diduga kandungan $\mathrm{N}$ dalam tanah yang terserap oleh akar tanaman dan pada jaringan tanaman lainnya sehingga mempengaruhi juga pada berat kering tanaman. Kombinasi pemupukan antara pupuk organik dan pupuk anorganik dapat meningkatkan serapan nitrogen oleh tanaman yang dibudidayakan, pada berbagai jenis lahan dan varietas (Kubát et al., 2003).

\section{KESIMPULAN DAN SARAN}

\section{Kesimpulan}

Dari hasil pengamatan dan pembahasan dapat disimpulkan sebagai berikut:

1. Frekuensi aplikasi 2 kali pada urea dengan arang sekam menunjukkan hasil yang lebih baik dibandingkan dengan frekuensi aplikasi 1 kali terhadap pertumbuhan bibit kakao.

2. Komposisi urea dangan arang sekam padi memberikan hasil tinggi tanaman, diameter batang, jumlah daun, luas daun, bobot kering brangkasan dan kandungan $\mathrm{N}$ tanaman terbaik adalah komposisi urea dengan arang sekam padi (1:2).

3. Terdapatkan interaksi yang nyata antara frekuensi aplikasi dan komposisi urea dengan arang sekam terhadap tinggi tanaman, luas daun dan jumlah daun.

\section{Saran}

Hasil penelitian yang telah dilakukan menunjukkan bahwa perlakuan frekuensi aplikasi 2 kali dengan komposisi urea : arang sekam padi (1:2) memberikan hasil yang maksimal sehingga disarankan untuk melakukan penelitian lanjutan untuk berbagai dosisi urea dan arang sekam dengan perbandingan 1:2.

\section{DAFTAR PUSTAKA}

Agustin, A. D dan M. Riniarti. 2014. Pemanfaatan Limbah Serbuk Gergaji. Edukasi, 1(1), 15-30.

Saragih, D., H. Hamim dan N. Nurmauli. 2013. Meningkatkan Pertumbuhan dan Hasil Jagung (Zea mays L.) Pioneer 27. J. Agrotek Tropika, 1(1), 50-54.

Semeon, P., Idwar dan A. Erlida. 2015. Uji Penggunaan Limbah Cair Biogas dan Pupuk N, P, K terhadap Pertumbuhan dan Arang Sekam Padi Sebagai Media Sapih Untuk Cempaka Kuning (Michelia champaca). Jurnal Sylva Lestari, 2(3), 49-58.

Audi, R. F. 2016. Pengaruh Berbagai Macam Sumber Bahan Organik Untuk Meningkatkan Pertumbuhan dan Hasil Tanaman Jagung di Lahan Pasir Pantai Sumas. Yogyakarta: Universitas Muhammadiyah.

Dwidjoseputro, D. 1980. Pengantar Fisiologi Tumbuhan (keenam). Jakarta: PT Gramedia.

Erida, N., Y. Yunus dan Yennita. 2013. Effect of Sedling Ages and Urea Dosages on Sedling Growth of Cacao. J. Floratek, (8) 10-17.

Enny, M., Endriani dan U.L. Sri. 2014. Pemanfaatan Urine Kelinci untuk Meningkatkan Pertumbuhan dan Produksi Tanaman Sawi (Brassica juncea L) Varietas Tosakan. IImiah Pertanian, 11(2), 23-34.

F. Fajarditta. 2012. Serapan Unsur Hara Nitrogen dan Phospor Beberapa Tanaman Legum pada Jenis Tanah yang Berbeda. Animal Agriculture, 1(2), 41-50.

Fatimah, S dan B. M. Handarto. 2008. Pengaruh Komposisi Media Tanam terhadap Pertumbuhan dan Hasil Tanaman Sambiloto. Embryo, 5(2), 133148.

Gustia, H. 2013. Pengaruh Penambahan Sekam Bakar pada Media Tanam terhadap Pertumbuhan dan Produksi Tanaman Sawi (Brassica Juncea L.). EJournal Widya Kesehatan dan Lingkungan, 1.

Kubát, J., J. Klír dan D. Pova. 2003. The Dry Matter Yields, Nitrogen Uptake, and The Efficacy of Nitrogen Fertilisation in LongTerm Field Experiments in Prague. Plant Soil Environ, 2003(8): 337-345.

Onggo, T. M., Kusmiyati dan A. Nurfitriana. 2017. Pengaruh Penambahan Arang Sekam dan Ukuran Polybag terhadap Pertumbuhan dan Hasil Tanaman Tomat Kultivar 'Valouro' Hasil Sambung Batang. Kultivasi, 16(1), 298-304.

Qodiriyah. 2019. Pengaruh Perendaman Air Panas dan Zat Pengatur Tumbuh ALami terhadap Pertumbuhan Bibit Tebu. Jurnal Bibit Kakao. Jom Faperta, 2(2).

Supriyanto dan F. Fiona. 2010. Pemanfaatan Arang Sekam untuk Memperbaiki Pertumbuhan Semai Jabon (Anthocephalus cadamba ( Roxb .) Miq) pada Media Subsoil. Silvikultur Tropika, 1(2086): 24-28.

Uli, K. P. S., S. Balonggu dan R. Nini. 2014. 
Jurnal Agroteknologi, Vol. 10 No. 2, Februari 2020 : 85 - 91

Respon Pertumbuhan Bibit Kakao

(Theobroma cacao L.) terhadap

Pemberian Abu Boiler dan Pupuk Urea

pada Media Pembibitan. Agroteknologi,

2(2337): 1021-1029. 